\title{
Autoethnographic Reflections of an International Graduate Teaching Assistant's Co-Teaching Experiences
}

\author{
Kristina M. Howlett \\ Huong L. Nguyen \\ The University of Arkansas, USA
}

\begin{abstract}
This authoethnographic study explores the co-teaching experiences of an international graduate teaching assistant (IGTA) assigned to co-teach an undergraduate course at a U.S. publicly funded university. As a sociocultural theoretical framework, Dewey (1938), Vygotsky (1978), and Schön's (1983) works regarding experiential learning, interaction, and reflective practice were used to analyze narratives and highlight the IGTA's co-teaching experiences to provide evidence of reflective and collaborative practices. Five themes emerged from the study: a need for professional development, interdependence, mentoring, improving interpersonal skills, and shifting perspectives. The findings uncovered how the coteaching experience cultivated and sustained an IGTA's personal awareness of self and others through guided reflection on instructional practices to improve teaching and learning.
\end{abstract}

Keywords: autoethnography, co-teaching, higher education, international graduate teaching assistants, professional development, sociocultural theory

\section{INTRODUCTION}

In recent years, the number of international graduate students enrolled in U.S. colleges and universities has grown rapidly, particularly for those who come from Asian countries (Lee, 2010). According to Kim (2012), Asian students represent 62\% of the international student population. Based on an annual report from the Institute of International Education (2017), the number of international students studying in 
the United States was 1,078,822 in the 2016-2017 academic year, a 3.4\% increase from the previous year. According to the higher education institution, international students are those who have or will request a non-immigrant visa (Institute of International Education, 2017). According to the Bureau of Labor Statistics (2017), there were 132,030 graduate teaching assistants (GTAs) employed at colleges, universities, and professional schools across the United States in May 2017. One of the primary reasons for the increased presence of international students on U.S. campuses is the rising middle class in those countries and a desire for students to attain social and cultural capital at universities in English-speaking countries (Finch \& Kim, 2012).

In publicly funded higher educational institutions in the United States, approximately half of the workload of GTAs is to teach university classes. Parker et al. (2015) indicated that graduate students teach the majority of first-year undergraduate courses at universities across the United States, Canada, and other countries. While some GTAs' jobs are to assist students following professors' lectures, an increasing number of GTAs serve as primary instructors in university classrooms and are responsible for developing lesson plans, delivering instruction, administering exams, grading papers, and providing feedback to students. Beyond the typical graduate student duties, international students face additional challenges in new educational environments, some of which are different worldviews, previous educational experiences, and linguistic demands.

Despite these shifting roles, many GTAs do not have specific training at the university level. Recently, the training of GTAs has received increased attention (Blouin \& Moss, 2015; Boman, 2013; Hoessler \& Godden, 2015; Kenny et al., 2014). Previous research suggests that many GTAs must learn from "on-the-job" or "sinkor-swim" immersion approaches (Chadha, 2013; Wise, 2011). There has been research on how to provide effective training for GTAs, among which is team teaching models with veteran professors. However, the research lacks studies on coteaching models with GTAs, particularly international graduate teaching assistants (IGTAs), who would benefit from professional development opportunities in the context of U.S. higher education institutions. This study fits into the current body of research conducted about co-teaching and GTAs. In the review of research, there were no studies of a team or co-teaching model with two IGTAs teaching in the same classroom at the university level; therefore, the general literature on co-teaching served as a foundation for the investigation. We argue that providing a co-teaching component to IGTA teacher training is important and doable for higher education institutions.

\section{BACKGROUND}

This study took place at a large publicly funded university in the fall of 2017 and spring of 2018. Two IGTAs had the assignment to co-teach an Introduction to Education course, a compulsory class for undergraduate students who are considering careers in education. One of the IGTAs is the second author, a Vietnamese $\mathrm{PhD}$ student in the Department of Curriculum and Instruction who had 7 years of experience teaching English learner undergraduates in Vietnam. The second IGTA 
had 1 year of experience teaching Chinese to speakers of other languages in China, and 6 months of experience teaching Chinese to children in the United States. The second IGTA was not part of the study. Therefore, neither IGTA had taught in public U.S. higher education institutions, but both had teaching experience.

\section{Researcher Roles}

The first researcher is an assistant professor of Teaching English to Speakers of Other Languages (TESOL) assigned to supervise and mentor the IGTA. The first author's interest in developing this study resulted from a lifelong interest in multicultural education, specifically with nonnative English students' success in higher education. Both researchers had the assignment to teach one of the Introduction to Education courses, but the professor had not been in a co-teaching role. Throughout the semester, the researchers met informally to discuss the course topics and the challenges and successes of teaching the course for the first time. At the end of the semester, the researchers decided that providing a narrative voice to the IGTA's first teaching experience at a U.S. university would be an important addition to the field of teacher education, specifically co-teaching, at a higher education institution.

\section{Research Question}

The primary research question is, "What are the reflections of an IGTA assigned to co-teach undergraduate students at a U.S. university?" There has been previous research with the voices of American undergraduate students who have had IGTAs as primary instructors; however, no studies were available examining the voice of an IGTA in a co-teaching model with another IGTA. This study acknowledges that there is a gap in the research. Therefore, the goal of this study was to provide the voice of an authentic experience of an IGTA.

\section{Co-Teaching and Team Teaching}

The terms co-teaching and team teaching are interchangeable. However, team teaching usually refers to two $\mathrm{K}-12$ general education teachers in the same classroom, and co-teaching involves a general education teacher and a specialist, usually a special education or teacher of English language learners, who are responsible for the same group of students. For this study, the term co-teaching is used, because this was the term used by the university.

The first model of two teachers in one classroom began in the 1960s in K-12 settings, so that special education students would have access to a mainstream education. Later on, the term "mainstreaming" changed to "inclusion," and the term "co-teaching" came into practice indicating that there would be a general education teacher and a specialist working together and responsible for the students' learning (Perry, 2017). The co-teaching model by Cook and Friend (1995) for special education and mainstream educators was to promote teaching together in general education classrooms because of the positive impacts on instruction and student 
performance. Friend and Cook (2007) developed six approaches that can guide effective co- teaching: (a) one teach, one observe, (b) one teach, one assist, (c) parallel teaching, (d) station teaching, (e) alternative teaching, and (f) team teaching (Table $1)$.

Co-teaching involves two or more instructors from either similar or different levels of expertise, within the same or different content area, coming together to discuss instructional goals and practice, and share accountability for the learning outcomes of the same class. Research findings from experimental studies in collaborative teaching have shown better learning outcomes, increased self-esteem, improved social skills and attitudes, and reduced absenteeism from students who receive instruction in this collaborative teaching model (Marshall, 2014).

\section{Table 1: Co-Teaching Models}

\begin{tabular}{ll}
\hline Method & Description \\
\hline $\begin{array}{l}\text { One teach, one } \\
\text { observe }\end{array}$ & $\begin{array}{l}\text { One teacher undertakes the main role of teaching while } \\
\text { the other teacher is in the position of an observer. The } \\
\text { second teacher steps back and observes what is going } \\
\text { on, focusing on either the first teacher's instruction, } \\
\text { students' learning, or interaction in the classroom. }\end{array}$
\end{tabular}

One teach, one assist

Parallel teaching

Station teaching

Alternative teaching
One teacher delivers instruction, while the other teacher helps by giving assistance to the first teacher or to students. This is an extension of the One Teach, One Observe model, with more involvement on the part of the second teacher.

The class divides into two equal groups and each instructor teaches one group. The biggest advantage of this model is that it reduces the student to teacher ratio.

The classroom is set up into three stations. Each instructor is in charge of one station, where he/she teaches one section of the lesson to one group of students and then repeats the same instruction to the second group.

Meanwhile, the first group rotates to the next station and continues to learn with the other instructor. After that, students move to the third station where they do independent work.

Two instructors simultaneously teach the same content information using two different approaches in order to address students' diverse learning styles. 
Team teaching

Both teachers are actively involved in the lesson delivery. One teacher might explain information as the other teacher demonstrates, or they take turns delivering instruction.

Note. Adapted from Bacharach et al., 2008; Graziano \& Navarrete, 2012.

Below is a graphic representation of the six co-teaching models.
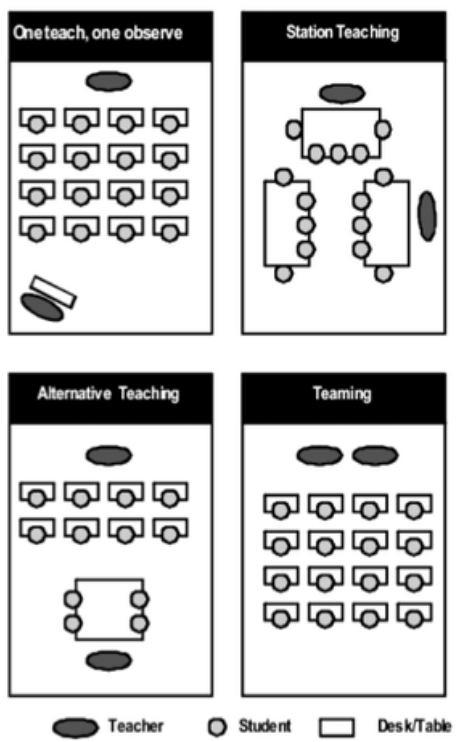
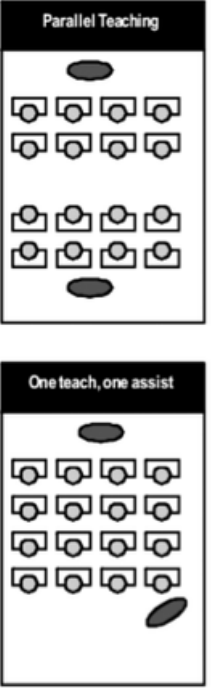

Figure 1: Co-Teaching Models (Adapted from Friend \& Cook, 2007)

\section{Graduate Student Teaching Professional Development}

Research on professional development for GTAs places an emphasis on the importance of consistent feedback from mentors (Nick et al., 2012). It is also important to attend multiple workshops throughout the semester (Mena et al., 2013; Richards et al., 2012), and observe teaching assistants within the classroom or laboratory (Cahalan, 2013; Santandreu Calonge et al., 2013). These professional development studies indicate that mandatory GTA training programs have greater effects compared with volunteer-based programs. In this study, attending classroom observations and mentor meetings were a requirement for the IGTAs' advisors; however, the co-teaching planning sessions were a voluntarily arrangement.

In graduate teaching education, mentoring can occur threefold with (a) faculty serving as mentors for GTAs, (b) senior or experienced GTAs mentoring newer GTAs, and (c) GTAs serving as mentors for undergraduates. Existing research 
underscores the value of continuous and extensive feedback from faculty mentors (Cho et al., 2011; Santandreu Calonge et al., 2013). Meeting regularly with faculty mentors benefits GTAs; they become aware of which aspects of teaching they need to improve and they receive advice on how to strengthen their teaching abilities (Cahalan, 2013; Chadha, 2013; Cho et al., 2011; Santandreu Calonge et al., 2013). The mentoring relationship has also proven beneficial to graduate students in professional development by helping them to become independent thinkers and researchers and strengthening their presentation skills for conferences (Lechuga, 2011). For this study, one senior and one junior faculty member served as mentors to the IGTA, who grew as an independent thinker and researcher.

\section{Sociocultural Theoretical Framework}

The sociocultural theoretical framework for this study branches from Dewey's (1938) model of experiential learning, the work of Schön (1983) on reflective practitioners, and Vygotsky (1978), who stressed the fundamental role of interaction and supported scaffolding learning through socially mediated contexts. Sociocultural theory postulates that the development of higher order processes are rooted in experience, in the socially situated context that is present in all human activities. According to Vygotsky (1978), these cognitive processes appear twice: first on the social level, and later on the individual level; first between people (interpersonal) and then inside (intrapsychological). The transformational process from interpersonal to intrapersonal is the result of a long series of developmental events. According to Creswell (2013), in social constructivism, individuals seek understandings of the world in which they live and work. In this study, the IGTA constructed knowledge based on experiential learning and social interactions and with the co-teacher and two mentors.

In reviewing Schön's (1983) seminal work on reflection, Wieringa (2011) stipulated:

Practitioners constantly need to define the problems by naming the things they will concentrate on and framing the context in which they will attend to them. The world is governed not by academic, formal knowledge, but by the knowing-in-action and reflection-in-action of practitioners. (p. 168)

At the core of this constructivist philosophy is the belief that knowledge is not given but gained through real experiences that have purpose and meaning to the learner, and the exchange of perspectives about the experience with others (Piaget \& Inhelder, 1969; Vygotsky, 1978).

\section{METHOD}

In order to deepen the knowledge of the lived experience of the IGTA's co-teaching experience, the study required autoethnography, a form of qualitative research in which an author uses self-reflection and writing to explore personal experiences and connects the autobiographical story to broader social meanings and understandings (Ellis, 2004; Maréchal, 2010). In this case, the IGTA was in the context of working 
with another IGTA, American undergraduate students, and American mentors at a U.S. higher education institution. Autoethnography is an emergent form of qualitative research inquiry that asks the primary question: "How does my own experience of my culture offer insights about this culture, situation, event, and way of life?" (Patton, 2015, p. 101). The ethnographic inductive analysis involves uncovering patterns, themes, and categories in the data analysis that must be organized, coded, and analyzed. Qualitative inquiry focuses on capturing, analyzing, and interpreting the story, which reveals our social nature (Patton, 2015), thereby highlighting the storytelling process. Using narrative analysis allows for stories and experiences to unfold looking for connections between cultural and social patterns.

Méndez (2013) noted critical advantages of autoethnographic research such as enabling the researcher's voice to be heard and the accessibility of data, because the researcher is the primary source and the root of the data. According to Couser (1997) and Goodall (2000), an autobiography must also illustrate new perspectives on personal experience - on epiphanies - by finding and filling a "gap" in existing, related storylines. Despite the fact that self is the source of data, it is important to maintain rigorous methods of data collection and analysis (Duncan, 2004). Richards and Morse (2012) observed that qualitative approaches to research are appropriate when:

The purpose is to learn from the participants in a setting or a process the way they experience it, the meanings they put on it, and how they interpret what they experience. You need methods that allow you to discover and do justice to their perceptions and the complexity of their interpretations. (p. 28)

\section{Data Collection}

The study used two types of triangulation. Method triangulation involved the use of data collection from handwritten notes from the IGTA's personal reflection journals, reflections from planning sessions with the co-teacher, and mentoring sessions with two advisors. After the co-teaching assignment ended, the researchers met weekly to discuss the epiphanies that the IGTA had selected for narrative reflections. At these meetings, the researchers read and discussed the nature of the reflection. Then, the researchers separated and analyzed the reflections. Upon reconvening, the researchers discussed similarities and differences in the analysis. Throughout the study, there was a method of cross-comparative analytic coding, highlighting words and phrases. Investigator triangulation involved the participation of two researchers in the same study to provide multiple analysis and conclusions. This type of triangulation involved confirmation of findings and different perspectives, adding to the phenomenon of interest (Denzin, 1978).

\section{Reflection Journals}

Every week, after teaching in the co-taught course, the researcher wrote a journal reflection related to what was happening in the class, what went well, and what did not go as smoothly as planned. Afterwards, the researcher met with a senior academic faculty advisor, Mentor A, to discuss the journal reflections describing what had 
transpired in class, what her co-teacher and she had done, and how the students performed the activities. Mentor A would comment on what the researcher said or asked for more detailed information. These required sessions took the written journal reflection one step further in the reflection process. After the course ended, the first researcher, Mentor B, suggested that the IGTA explore the epiphanies of the coteaching experience by reviewing the planning session notes, mentoring sessions with Mentor A, and reflection journals. Therefore, the IGTA began a second mentoring experience, as well as a second journaling process with Mentor B.

\section{Planning Sessions}

Careful and thorough preparation for a lesson is needed prior to teaching a class (Gunter et al., 2007; Ploessl et al., 2010), and this is even more critical for cooperative teaching where ongoing, collaborative planning sessions are required (Waters \& Burcroff, 2007). These planning sessions should be well-structured in advance by having the purpose, goals, and meeting location identified (Ploessl et al., 2010). To ensure that the instructional approach would be successful, the co-teachers furthered their knowledge by attending weekly observations of two veteran teachers' classrooms, one with the director of the teacher education program and the other with a GTA who had several years of $\mathrm{K}-12$ teaching experience. The IGTAs met on a weekly basis at a mutually convenient time. At these meetings, the co-teachers discussed their notes taken from the joint classroom observations and made decisions about how to approach the weekly teaching lessons.

\section{Mentoring Sessions}

There were two mentoring periods. During the course of the semester, the IGTA had mentor sessions with a senior academic faculty advisor, Mentor A, to discuss the reflective journals written after each class. Afterwards, when the course ended, the IGTA began to collaborate with the first researcher, Mentor B, to write the narrative of the autoethnographic study. During the second mentoring session with Mentor B, the IGTA had an opportunity for more in-depth discussions and additional reflective journals.

\section{Procedures}

After the course had ended, the researcher (Mentor B), who was serving as the IGTA's new graduate advisor, suggested that the deep analysis should include the most salient co-teaching learning experiences. Therefore, a second reflective cycle took place providing additional process time. From December to January, the IGTA reviewed the planning session notes, reflective journals, and Mentor A session notes. Then, the IGTA selected epiphanies based on the co-teaching experience. The researchers read each reflection independently and later aloud, and the co-researchers discussed emerging themes. The first stage was open coding, the process of identifying and naming chunks of data. This study utilized a grounded theory perspective (Charmaz, 2006) with a theoretical orientation in the views or 
perspectives of the individual researcher. The emergent epiphanies from this second reflective learning cycle include the data analyzed for the findings.

\section{RESULTS}

In Figure 2, the conceptual Reflective Diagram of Professional Development (adapted from Wallace's 1991 Reflective Model of Professional Education or Development) represents the reflective model as a cyclical process whereby the IGTA in training was involved throughout the teaching experience. The goal of this cycle is for continuous improvement and the development of personal theories of action, as resulted in the current study. The IGTA received new knowledge, practiced, reflected, and achieved the end goal, increasing professional competence. Through working in partnership with the co-researcher, the IGTA engaged more deeply in learning and teaching. This type of partnership is what Vygotsky (1978) defined as scaffolding, a collaborative process promoting cognitive development through sociocultural interactions.

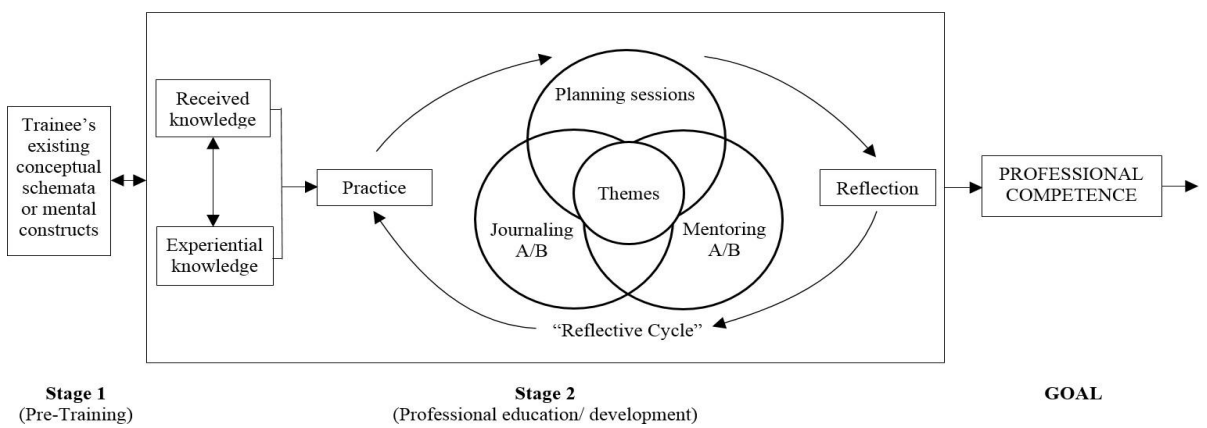

Figure 2: Reflective Diagram of Professional Development (Adapted from Wallace's 1991 Reflective Model of Professional Education or Development)

\section{Narrative Analysis and Themes}

The following section includes five reflective narratives and accompanying themes that emerged from the study. Analyzing the data consisted of reading the reflections multiple times, and identifying key sentences, phrases, or quotes found in the IGTA's selected epiphanies. The recurring themes derive from multiple interpretations of the IGTA's reflection journals, planning sessions, and mentoring sessions supporting the triangulation of data, a recursive rather than linear process.

\section{Narrative Analysis and Themes}

Reflection 1. No one advised us on how to design our co-teaching plan, so we just met and discussed what needed to be done. In fact, before the course started, my co-teacher and I discussed two possible approaches we could 
take for our collaborative teaching. The first one involved each of us teaching the class for one day and the other approach involved taking turns to teach in every class. The advantage of the first approach was that we would not need to be present in class every week. However, I insisted that even when I was not teaching, I still would like to observe, so the second approach would be best for me, so, she agreed that both of us would be there and take turns teaching. (Planning Session, August 14, 2017; Mentoring/CoResearcher Session B, December 8, 2017).

We did not realize there were several different co-teaching models. Afterwards, when I began conducting research on co-teaching, I realized that we mainly focused on three of the models: One teach, one observe; one teach, one assist; and teaming. We practiced these models in our teaching, without being aware of them, because we felt comfortable collaborating in such ways. If I have the opportunity to co-teach again, I would like to try other models" (Mentoring Session A, October 9, 2017; Mentoring/CoResearcher Session B, December 15, 2017).

Theme 1: Need for Professional Development. Co-teaching is not only an art, but it is also a science. Teachers require professional development to learn the specific nuances of various models, in order to integrate the models into their lesson planning practices. In this narrative, the co-teachers were unaware of various models, and they would have benefitted from attending workshops or ongoing job-embedded professional development. In this case, the IGTA began to study the co-teaching model and reflect on the teaching practices. For Dewey (1938), the basis of, and reason for reflection was the necessity of solving problems faced in habitual ways of action. Dewey also showed that hypotheses reflection, as articulated by the IGTA, "If I have the opportunity to co-teach again, I would like to try other models," can only be tested in experimental activity, which might solve the problem that elicited the process of reflection.

In order for a professional partnership to reach its full potential, training on coteaching is desirable to equip IGTAs with knowledge about various co-teaching formats, discuss which approach to implement in specific learning situations, and allow practice time in a teaching assistantship workshop before teaching. Insufficient training may hinder successful results because effective co-teaching does not simply involve putting two teachers in the same classroom. As Ploessl et al. (2010) contended, "Good co-teaching involves two teachers who are actively teaching and monitoring students, not one teacher and an additional pair of hands" (p. 164). Furthermore, Parker et al. (2015) concluded from their study on their first institutionwide graduate assistant teacher-training program that the program not only equipped graduate assistants with applied learning experiences but also brought benefits for multiple stakeholders within their institution.

Reflection 2. Each week, both of us would observe two other instructors who taught the same course but with different students. We would go to the classes, observe, and take notes on the activities used in each class. After 
that, we had co-teaching meetings to decide which activities we thought were successful and wanted to adopt for our own class. We then wrote our agenda for the weekly lesson. Our co-teaching planning sessions were in the GA [graduate assistant] office, with both of us working on the same Google document. We talked, discussed, wrote and edited directly on our shared Google document. The chosen activities were based on the topic of the week and the observed effectiveness in the veteran instructors' classrooms. Once the lesson agenda had been finished, we made the PowerPoint slides and copies, and decided who would take charge of which activity. We did this on a voluntary basis as well. (Planning Session, September 9, 2017; Mentoring Session A, November 20, 2017).

Most of the time, my co-teacher and I collaborated well. However, there were times when we had different ideas on how to teach certain parts of a lesson. In such cases, each of us would give reasons why we wanted to include or not include one part and why we thought the most appropriate way to do it was that way. In other words, each of us tried to persuade the other with a justification, and then we would come to a compromise on how to do the activity. (Mentoring Session A, December 11, 2017; Mentoring/Co- Researcher Session B, January 29, 2018).

Theme 2: Interdependence. In this reflection, co-teaching is an interdependent process of planning and sharing responsibilities. The organic nature of how the coteaching planning sessions developed, with the teachers working both independently and collaboratively, reflects how interdependence came about. The IGTAs were aware that collaborative planning was crucial to the success of co-teaching (Graziano et al., 2012). As Henderson et al. (2009) asserted, "The defining feature of coteaching is that the participants share responsibility for all aspects of a class" (p. 276). Another characteristic that facilitated a successful partnership was the formation of a trusting relationship, as demonstrated by the joint responsibilities in designing and completing the lessons on a voluntary basis.

As Graziano et al. (2012) maintained, "The most preferred style of team teaching involved two instructors who were in the classroom together for all class meetings" (p. 113). Although the IGTA did not shadow a professor, having another fellow GTA in the classroom to collaborate in instructional delivery provided an interdependent relationship that helped ease the way into an overwhelming first semester of teaching American students at the college level.

Reflection 3. Another lesson learned was from the mentorship provided by advisors. Both my co-teacher and I enrolled in teaching internships with our respective advisor. My co-teacher's advisor came to observe our class twice. After each observation, the advisor would send feedback on how well the lesson was taught and what should be improved. My co-teacher shared the feedback with me, and although it was mainly on her performance, I was able to learn, too. For example, the mentor noticed that some students in our class had difficulty understanding spoken instructions. The mentor advised providing directions both orally and in writing to ensure students understood 
what they were supposed to do. The addition of providing directions orally and in writing improved our practice by assisting our students' comprehension.

As for my academic advisor, she asked me to write reflections on my teaching, and I met with her to discuss my reflections. Thanks to these meetings, I adopted a habit of reflection towards my teaching practice. I believe I benefited tremendously from both types of mentoring, class observations by my colleague's advisor, reflections and discussions with my own academic advisor. (Journal B, October 21, 2017; Mentoring CoResearcher Session B, January 12, 2018).

Theme 3: Mentoring. The mentors' feedback assisted the co-teacher in further reflection of her practice. The benefits included an open forum for the discussion of teaching and development of greater confidence in classroom instruction. The mentoring experience may be the formal opportunities for IGTAs to clarify a welldefined philosophical approach to teaching, which will assist them in applying for future university jobs. According to Schön (1983), reflection is a continuous process, whereby the learner is allowed to engage in ongoing reflection. The process of mentoring and reflection was new and significant for the IGTA in this study, who had started a teaching career in her home country but never had the experience of working with mentors and asking to reflect on classroom practices.

Reflection 4. As an introvert, I noticed I was not good at providing "small talk" with students. I was grateful that my co-teacher did that so gracefully, and I was able to learn from her. On Week 1, we learned that several students came from Texas. On Week 2, my co-teacher greeted them by asking how they felt after the first week at college. She addressed Hurricane Harvey, which struck Texas the previous weekend and expressed concerns for students who had family in Houston. She asked if their loved ones were safe, and she offered to lend support. I came into teaching feeling nervous and not knowing what to do, but throughout the semester, as I observed how my coteacher used small talk to build rapport with students, I acquired the relationship-building skills, and I gradually took charge of more activities. (Journal A, October 28, 2017; Mentoring Session A, October 30, 2017).

Theme 4: Improved Interpersonal Skills. Partnered with a colleague who had different personality traits was one of the major benefits for the IGTA. In the beginning, the introverted teacher was anxious and not sure what to say to start class. However, when the co-teacher began the class with ease, the co-teacher was able to step back and observe and gained a greater awareness of her colleague's interpersonal skills in the area of small talk. By modeling how to begin the class with small talk, the teacher learned how to use this technique and eventually started class on her own. The IGTA knows that interpersonal skills help in forming relationships and building trust with future students. Co-teachers can watch and learn from each other about how to effectively form bonds and build relationships with students, which aids in the learning process. This example underscores Vygotsky's zone of proximal development, which is the actual development of independence (i.e., what the learner 
is able to do independently.) In this case, the IGTA stepped back and observed her colleague's success with small talk, and the learning became part of a larger process in terms of the ever-shifting needs of the learner.

Reflection 5. The major assignment for the course was the Philosophy of Education paper. In order to assist our students, we decided to have them work in groups of three and give feedback to their peers' first and second drafts. I thought that a simple quick way to divide students would be to assign students to groups, but my co-teacher wanted to buy chocolate with different colored wrappers, and those who picked the same colors would join the same group. My first thought was it was not necessary to group students in this childish and time-consuming way. However, the activity turned out to be fun; students were thrilled when they randomly selected a chocolate and were excited to see who would land in their group. (Planning Session, October 19, 2017; Journal A, November 11, 2017; Mentoring Session A, November 13, 2017).

When my co-teacher was teaching one part, I had the opportunity to step back and observe. I noticed how she delivered the part, and how students reacted and performed the task. I would ask myself as I was observing, "If I were to teach the same part, would I be doing the same as her? If not, what would I do differently, and why?" If I were the only teacher, I would frequently think about teaching the lesson in a "fixed way," and that my way was the best way. However, when I observed my co-teacher teaching, I had the chance not only to look at the lesson from another perspective, but also to become more critical about my own practices. (Journal A, September 23, 2017; Mentoring Session A, September 25, 2017).

I shared with our students that I used to teach to the test because the curriculum where I taught was based heavily on rote drill and test practice. Now I am more inclined towards progressivism, because I believe this approach builds students' problem-solving skills as they learn by doing and discovering things by themselves. My co-teacher, on the other hand, believes that behaviorism plays a pivotal role in education, a belief based on her home country's educational system. Exposing students to our divergent viewpoints may have helped our students see the same issue from different angles. (Journal A, October 14, 2017; Mentoring Session A, October 16, 2017).

Theme 5: Shifting Perspectives. The teaching partnership provided opportunities for the IGTAs to get out of their comfort zones, try out new instructional practices, and work collaboratively. One co-teacher's major was childhood education, and she had more experience integrating manipulatives and the arts into lesson planning. Working with a creative teacher opened up the IGTA's mind to try elementary-type approaches in a university level classroom, thus expanding the teacher's pedagogical repertoire. The second teacher also influenced the first teacher in a positive way. As a TESOL major who had knowledge of language and culture, this teacher discussed how the American students were adjusting to the co-teachers' 
accents and this assisted the other co-teacher in understanding the sociocultural dynamics of the classrooms. Working collaboratively opened up the teachers' minds to thinking and acting differently, thereby shifting perspectives.

The co-teachers expressed differing philosophical perspectives to their students; one teacher wanted to move towards progressivism, while the other co-teacher relied heavily on values of behaviorism. While contrasting philosophies could be a challenge in co-instructional delivery, especially when one teacher prefers a teachercentered approach and the other prefers student-centered, the articulations did provide students with different perspectives. This finding is echoed in previous studies. For example, one of the participants in Vogler and Long's (2013) study on team teaching commented, "Having two teachers does help reinforce the lesson" (p. 125). Harris and Harvey (2000) noted that students appreciate their instructors examining theories and concepts differently. Co-teaching is an effective way to model and develop the collaborative skills that are necessary for teacher candidates. According to Gentry (2012), "In schools and universities, teacher education candidates do not gain extensive training and experience in collaborative teamwork" (p. 1). Students taking the Introduction to Education course were those who had interest in becoming teachers. Seeing two instructors teaching collaboratively every week in class, how they assisted one another when carrying out activities, how they divided tasks and responsibilities, and how they handled difficult situations, students had the opportunity to observe ways to develop their own interpersonal skills and work effectively with future teacher colleagues.

The shifting perspectives theme underscores Schön's (1983) model of the reflective practitioner whereby the IGTA was reflecting-in-action, in the moment and unconsciously, as well on reflecting-on-action, after teaching and consciously. Therefore, the co-teaching partnership promotes an environment of peer-to-peer interaction and pushes the IGTA into deeper unconscious and conscious reflection, an important trait of professional artistry. Schön found that teachers who were involved in reflection on emergent practice enhanced their practice. Having another instructor in the classroom allows the co-teaching partners to observe and implement different teaching strategies, such as lecturing, discussion, and small group work (Walter \& Misra, 2013).

\section{CONCLUSION}

\section{Limitations}

While the data present insights about the notion of a co-teaching model for IGTAs, the autoethnography is limited to the narrative reflections of only one individual, a Vietnamese IGTA in one higher education setting. Therefore, there is a limit to the generalizability of the findings. The data is also self-reported and limits the capacity to make claims about other IGTA learning. While the data from the study is limited to only one IGTA's reflections, findings showed that the co-teaching model provided a socially constructed environment that fostered reflective practice for improved lesson planning, observations, instructional delivery, and course outcomes. This co-teaching model, although largely unstructured, was integral in deepening 
self-reflection between two IGTAs who were in the situation of co-observing veteran instructors, discussing observations, and planning weekly lessons.

\section{Conclusion}

The aim of this qualitative study was to investigate the reflections of an IGTA co-teaching U.S. undergraduates for the first time and reflecting upon actual classroom experiences. By capturing the voices of IGTAs, the field of university teacher-training programs can learn about ways to use collaborative professional development models. The co-teaching model with IGTAs is an underresearched area in higher education settings that warrants further study. While the data from the study is limited to only one IGTA's reflections, findings showed that the co-teaching model provided a socially constructed environment that fostered reflective practice for improved lesson planning, observations, instructional delivery, and course outcomes.

\section{Recommendations}

Based on the findings, the authors recommend three areas for additional research, especially because the number of IGTAs at American colleges continues to grow. The influx of IGTAs has presented universities with the need to expand professional development, and one promising practice observed in this study is co-teaching, a completely different approach to the standard professor-TA model. A starting point is to begin co-teaching in the colleges of education, branching out to the social sciences.

The results from this study indicated that additional professional development would be essential at the university level. Developing workshops would assist IGTAs to work in collaborative learning environments not only with faculty members, but also with other GTAs in order to stress the importance of interdependence and increased interpersonal skills, themes that emerged from the study. Therefore, the first recommendation is to provide professional development and intentional co-teaching models at postsecondary institutions with experienced native and nonnative Englishspeaking GTAs working closely together along with cross-cultural training, so that all students can increase intercultural competencies, a critical skillset in today's global society. While there might be unequal power dynamics between native and nonnative GTAs, the authors believe that the benefits of cross-cultural training would outweigh the challenges. By developing empathy, cultural understanding, and collaborative skills at colleges and universities, these global competencies can better prepare all students to enter the workplace.

The second recommendation is to expand mentorship with two professors providing feedback to IGTAs. The findings resulted in an inclusive co-creative approach with the IGTA's partnership with two advisors. This study is significant because the IGTA was working in a new teaching environment in the United States and was learning from veteran instructors and mentors. Further research could study nonnative English-speaking faculty serving as mentors, veteran GTAs mentoring IGTAs, or international advisors. Teacher education programs must look for ways to build community within and across school-university settings and consider co- 
teaching as one of the potential new promising practices to advance cross-cultural efforts and intercultural competencies.

The final recommendation is to implement guided written reflections throughout and after the teaching experience. This autoethnographic research study uncovered how the co-teaching experience cultivated and sustained the IGTA's personal awareness of self and others through guided storytelling reflection. This study supports the importance of allowing researchers to reflect and tell their personal stories in order that they become better teachers and researchers. The IGTA researcher explored a personal teaching and learning experience, co-teaching, that yielded meaningful results while making connections to the research process. While co-teaching is not a traditional practice in higher education, the rich opportunities for reflection on IGTA teaching practices and growth as a reflective practitioner presented in this study can serve as a starting point for co-teaching at the college level.

\section{REFERENCES}

Bacharach, N., Heck, T. W., \& Dahlberg, K. (2008). Co-teaching in higher education. Journal of College Teaching \& Learning, 5(3), 9-16.

Blouin, D. D., \& Moss, A. R. (2015). Graduate student teacher training: Still relevant (and missing?) 20 years later. Teaching Sociology, 43(2), 126-136. doi:10.1177/0092055X14565516

Boman, J. S. (2013). Graduate student teaching development: Evaluating the effectiveness of training in relation to graduate student characteristics. Canadian Journal of Higher Education, 43(1), 100-114.

Bureau of Labor Statistics. (2017). Occupational employment statistics. Retrieved on September 7, 2018 from https://www.bls.gov/oes/current/oes251191.htm

Cahalan, J. M. (2013). Teaching classroom videorecording analysis to graduate students: Strategies for observation and improvement. College Teaching, 61(2), 44-50.

Chadha, D. (2013). Reconceptualizing and reframing graduate teaching assistant (GTA) provision for a research-intensive institution. Teaching in Higher Education, 18(2), 205-217. doi:10.1080/13562517.2012.696537

Charmaz, K. (2006). Constructing grounded theory: A practical guide through qualitative analysis. Sage.

Cho, Y., Kim, M., Svinicki, M. D., \& Decker, M. L. (2011). Exploring teaching concerns and characteristics of graduate teaching assistants. Teaching in Higher Education, 16(3), 267-279. doi:10.1080/13562517.2010.524920

Cook, L., \& Friend, M. (1995). Co-teaching: Guidelines for creating effective practices. Focus on Exceptional Children, 28(3), 1-16.

Couser, G. T. (1997). Recovering bodies: Illness, disability, and life writing. University of Wisconsin Press.

Creswell, J. W. (2013). Qualitative inquiry and research design: Choosing among five approaches (3rd ed.). Sage.

Denzin, N. K. (1978). Sociological methods: A sourcebook. McGraw-Hill.

Dewey, J. (1938). Experience and Education. Collier Books. 
Duncan, M. (2004). Autoethnography: Critical appreciation of an emerging art. International Journal of Qualitative Methods, 3(4), Article 3.

Ellis, C. (2004). The ethnographic I: A methodological novel about autoethnography. AltaMira.

Finch, J., \& Kim, S. K. (2012). Kirŏgi families in the US: Transnational migration and education. Journal of Ethnic and Migration Studies, 38(3), 485-506.

Friend, M., \& Cook, L. (2007). Interactions: Collaboration skills for school professionals (5th ed.). Pearson Education.

Gentry, R. (2012). Collaboration skills pre-service teachers acquire in a responsive preparation program. Journal of Instructional Pedagogies, 8, 1-9.

Goodall, H. L. (2000). Writing the new ethnography. AltaMira.

Graziano, K. J., \& Navarrete, L. A. (2012). Co-teaching in a teacher education classroom: Collaboration, compromise, and creativity. Issues in Teacher Education, 12(1), 109-126.

Gunter, M. A., Estes, T. H., \& Mintz, S. L. (2007). Instruction: A models approach (5th ed.). Allyn \& Bacon.

Harris, C., \& Harvey, A. N. C. (2000). Team teaching in adult higher education classrooms: Toward a collaborative knowledge construction. In New directions for adult and continuing education (pp. 25-32). Jossey-Bass Publishers.

Henderson, C., Beach, A., \& Famiano, M. (2009). Promoting instructional change via co-teaching. American Journal of Physics, 77(3), 274-283.

Hoessler, C., \& Godden, L. (2015). The visioning of policy and the hope of implementation: Support for graduate students' teaching at a Canadian institution. Canadian Journal of Higher Education, 45(1), 83-101.

Institute of International Education. (2017). International student enrollment trends, 1948/49-2016/17. Open doors report on international educational exchange. Retrieved on January 24, 2018 from http://www.iie.org/opendoors

Kenny, N., Watson, G. P. L., \& Watton, C. (2014). Exploring the context of Canadian graduate student teaching certificates in university teaching. Canadian Journal of Higher Education, 44(3), 1-19.

Kim, E. J. (2012). Providing a sounding board for second language writers. TESOL Journal, 3(1), 33-47.

Lechuga, V. M. (2011). Faculty-graduate student mentoring relationships: Mentors' perceived roles and responsibilities. Higher Education, 62(6), 757-771.

Lee, J. J. (2010). International students' experiences and attitudes at a US host institution: Self- reports and future recommendations. Journal of Research in International Education, 9(1), 66-84.

Maréchal, G. (2010). Autoethnography. In A. J. Mills, G. Durepos, \& E. Wiebe (Eds.), Encyclopedia of case study research, (Vol. 2, pp. 43-45). Sage.

Marshall, A. M. (2014). Embedded professional development for teacher educators: An unintended 'consequence' of university co-teaching. International Journal of University Teaching and Faculty Development, 5(1), 17-30.

Mena, I. B., Diefes-Dux, H. A., \& Capobianco, B. M. (2013). Socialization experiences resulting from doctoral engineering teaching assistantships. Journal of Higher Education, 84(2), 189-212. 
Méndez, M. (2013). Autoethnography as a research method: Advantages, limitations and criticisms. Colombian Applied Linguistics Journal, 15(2), 279-287.

Miettinen, R. (2000). The concept of experiential learning and John Dewey's theory of reflective thought and action, International Journal of Lifelong Education, 19(1), 54-72.

Nick, J. M., Delahoyde, T. M., Del Prato, D., Mitchell, C., Ortiz, J., Ottley, C., Young, P. K., Cannon, S. B., Lasater, K., Reising, D. L., \& Siktberg, L. (2012). Best practices in academic mentoring: A model for excellence. Nursing Research and Practice, 2012, Article 937906. doi:10.1155/2012/937906

Parker, M. A., Ashe, D., Boersma, J., Hicks, R., \& Bennett, V. (2015). Good teaching starts here: Applied learning at the graduate teaching assistant institute. The Canadian Journal of Higher Education, 45(3), 84-110.

Patton, M. Q. (2015). Qualitative research \& evaluation methods: Integrating theory and practice (4th ed.). Sage.

Perry, A. (2017). A brief history of co-teaching. Retrieved on February 20, 2018 from https://www.cultofpedagogy.com/co-teaching-push-in/

Piaget, J., \& Inhelder, B. (1969). The psychology of the child. Basic Books.

Ploessl, D. M., Rock, M. L., Schoenfeld, N., \& Blanks, B. (2010). On the same page: Practical techniques to enhance co-teaching interactions. Intervention in School and Clinic, 45(3), 158-168.

Richards, K. A., Velasquez, J. D., \& Payne, L. B. (2012). The influence of a college teaching workshop series on teaching assistant perceptions of preparedness and self-efficacy. Proceedings of the ASEE Annual Conference (Session 4433). Washington, DC: ASEE.

Richards, L., \& Morse, J. M. (2012). Readme first for a user's guide to qualitative methods. Sage.

Santandreu Calonge, D., Mark, K. P., Chiu, P. H., Thadani, D. R., \& Pun, C. F. (2013). Extreme-Teaching-2 (XT' $\left.{ }^{2}\right)$ : Evaluation of an innovative semester-long intensive GTA training program based on microteaching. International Journal of Teaching and Learning in Higher Education, 25(1), 129-143.

Schön, D. (1983). The reflective practitioner How professionals think in action. Basic Books.

Vogler, K. E., \& Long, E. (2013). Team teaching two sections of the same undergraduate course: A case study. College Teaching, 51(4), 122-126.

Vygotsky, L. S. (1978). Mind in society: The development of higher psychological processes. Harvard University Press.

Wallace, M. J. (1991). Training Foreign Language Teachers: A Reflective Approach. Cambridge University Press.

Waters, F. H., \& Burcroff, T. L. (2007). Collaborative teaching at the university level: Practicing what is preached. The Teacher Educator, 42(4), 304-315.

Wieringa, N. (2011). Teachers' educational design as a process of reflection-inaction: The lessons we can learn from Donald Schön's The reflective practitioner when studying the professional practice of teachers as educational designers. Curriculum Inquiry, 41(1), 167-174. doi:10.1111/j.1467-873X.2010.00533.x

Wise, A. (2011). Supporting future faculty in developing their teaching practices: An exploration of communication networks among graduate teaching assistants. 
International Journal of Teaching and Learning in Higher Education, 23(2), $135-149$.

KRISTINA M. HOWLETT, PhD, is an Independent Researcher and Community Projects Coordinator/College Advisor for the Rogers Honors Academy, Rogers Public Schools, in Rogers, Arkansas. She also chairs the Scholarship/Awards Committee for ARKTESOL (Arkansas Teachers of English to Speakers of Other Languages). Her major research interests include ESOL teacher training and professional development, service learning, biliteracy, and multiculturalism. Email: kristinahowlett@gmail.com

HUONG L. NGUYEN, MA, is a doctoral candidate and graduate assistant in the Department of Curriculum and Instruction at the University of Arkansas in Fayetteville, Arkansas. Her major research interests lie in the areas of teaching English to Speakers of Other Languages (TESOL), international graduate teaching assistant professional development, and technology development in English learner (EL) instruction. Email: hlnguyen@uark.edu 